\title{
A golden age of security and education? Adult education for civil defence in the United States 1950 - 1970
}

\author{
Professor John Preston, University of East London
}

Contact details: Professor John Preston (j.j.preston@uel.ac.uk), Cass School of Education and

Communities, University of East London, Water Lane, Stratford, London, E15 4LZ: 0208223337

Word count: 11048 words

\section{American exceptionalism in education and security?}

The US (United States of America) is well known for a government that has aggressively pursued the domestic security of its citizens through community, and national level, strategies. In its most recent formation, this is known as 'Homeland security' which tries to mobilise a range of national resources (Fosher, 2010; Collier and Lakoff, 2011) but this is not a contemporary phenomenon. The US has a long history of using 'civil defence' initiatives to protect its population. Primarily, these were designed to provide the US population with protection from nuclear, rather than terrorist attack. These have been aimed not only at children, but also at adults. The Cold War was a period in which the concerns of the intelligence agencies and military strategists concerning the readiness of the population to face nuclear war, entered into almost every sphere of civil society. This paper, considering adult education in the cold war US, presents an opportunity to see how education and security were aligned, or not, in line with the theme of this special issue. As Steedman $(1992$, p.55) specifies as an aim of the history of education, it seeks to place education within the social and political landscape of the time, in this case with particular concern for security.

What characterises the US approach, and makes it distinctive from the way that other countries deal with population protection is twofold. Firstly, it has (historically) been pedagogically rich using pedagogies that are not only didactic, but also those which consider family, community and affective forms of learning. Rather than tell the population what to do, the US government's civil defence initiatives of the 1950s and 1960s concentrated on 'duck and cover' in schools (where children were taught to hide beneath their school desks), constructing 'family fallout shelters' and rehearsing nuclear drills in communities. The second thing that defines the US approach is that it has been a national endeavor. Despite having a federal system, the US government has historically imposed centralised policies which are very different to other federal systems such as Germany (Preston, Chadderton and Kitagawa, 2014). In short, there seems to be a prima facie case for US exceptionalism in terms of civil defense education. Education and security were closely linked, and it is quite plausible that the strategic nuclear policy of the US was mirrored in its education system. This paper considers that, at least in the realm of adult education in this period, this was only partially the case.

On the surface, the US system of adult civil defence education was societal and extremely effective. In this period, civil defence activities seemingly saturated American society through Duck and Cover drills, public shelters, radio announcements, emergency broadcasts, short films on nuclear war, rural civil defence, adverts and popular cultural representations of mutants and radioactive monsters. Recent 
appraisals of US cold war civil defence consider that it was not just nuclear kitsch (Preston, 2012, p.29), but was a totalizing societal phenomenon during this period. Depictions of the US of this time as a 'civic garrison' (Grossman, 2001) or a 'militarised' society (McEnaney, 2000) consider that civil defence was universal and pervasive, a key component of national security. At a macro level, it is argued, the state imposed civil defence onto an acquiescent, population, which permeated every aspect of life at a micro level. In some areas of education, there is support for this position. Grossman (2001) shows how the FCDA (Federal Civil Defense Administration) had a major influence on research universities, directing them towards nuclear and civil defence activities. Brown (1988) considers that, rather than the top-down nature of civil defence, it was actually the actions of teachers and educators who wanted to introduce the bomb into the classroom until ultimately 'Civil defense became a way of life in American schools' (Brown, 1988, p.90). Science education was revolutionized and basic science (albeit in an ideological fashion) became an integral part of educational curricular (Rudolph, 2002). Outside of the academic sphere, Conelrad.com, a remarkable website dedicated to the preservation and rediscovery of cold war culture, refers to civil defence in the 1950s and 1960s as a 'golden age of homeland security'. The cold war even influenced visual culture and media in the USA ( Bassnett, Nobile and Phu, 2015). In the institutional memories of agencies such as FEMA (Federal Emergency Management Agency) and the DHS (Department of Homeland Security) the period has become an iconic period of American preparedness where education and security were closely entwined.

Ball (2006, p.31) frequently refers to the mistaken belief, in education policy more generally, that there is a 'golden age' when things were much better than they are today. This belief that there was a golden age applies to many areas of education such as academic work in universities (Tight, 2010), educational architecture (Seabourne, 2006) and vocational education (Fisher, 2010). There is sometimes an element of truth in 'golden ageism' but often it reflects the contemporary desire to invoke a romantic fantasy of the past. For example, after the $9 / 11$ attacks on the US, there was a desire in certain elements of US society to return to educational efforts reminiscent of cold-war civil defence (Preston, 2009). To some extent, civil defence of the 1950s and1960s has been considered to be a 'golden age' of Homeland Security. However, this alleged triumph of securitization (even if it did exist) must be considered alongside a political environment in which paranoia and fear of Communist subversion were part of mainstream discussion. The aims of the FCDA were very much in the tradition of Hofstadter's (2008) 'paranoid style' of American politics and if a 'golden age of homeland security were to have emerged during this period it would have been at the expense of civil liberties in creating a 'garrison state'.

Grossman (2001), McEnaney (2000) and Brown (1988) are correct to consider that civil defence was enormously influential in certain domains of American educational life, although they underplay the active political resistance to 'Duck and Cover' type activities at the time (Garrison, 2006). However, much of their analysis is based upon the records of the FCDA, and related organisations, or teacher and civil society groups that were generally in favor of civil defence activities. Such evidence has an inherent bias. Civil defence in the US was actively sold to the American public, hyping successes and downplaying failures, and agencies such as the FCDA would often rely on anecdotal evidence to support their claims of a widespread take up of these activities. This paper adopts a different approach. Rather than considering the perspective of the FCDA (and other agencies) as super-ordinate, driving other government departments, I consider the responses of one of the 'driven' agencies (the Department of Health, Education and Welfare) and, in particular, the OE (Office of Education) within that agency to consider the relative success of one aspect of civil defence: adult education. This reveals a very different picture where education policy makers, and adult learners, were largely resistant to the 
security agenda at this time. What did emerge was a version of civil defence in which educators were accommodative, rather than simply compliant.

\section{Approach}

The approach taken in this research was archival. The method involved interrogating the historical records of a federal agency (the DHEW, and the historical period covered by the paper $(1950-1970)$ is broad and covers a number of Presidents, wars, crisis and changes in institutional structures for civil defence. According to Collier and Lakoff (2008) the period 1950 - 1970 was bifurcated by a change in US domestic security strategy. The period 1950 - 1960 was one which was focused on civil defence whereas the period 1960 - 1970 was one where an all-hazards approach was adopted, with an increasing use of civil defence resources for purposes other than preparation for nuclear war. Broadly, this does concur with the societal emphasis on civil defense throughout the Truman administration (1945-53) (Grossman, 2001) and, to a lesser extent Eisenhower (1953 - 1961) (whose "Interstate Highways Act" created a transport system with the explicit purpose of evacuation and mobilization: Kuklick, 2009). Although Truman was a fiscal conservative, the military demands imposed by NSC68 and the economic argument that military expenditure would have expansionary economic effects resulted in a massive increase in defense spending at home and abroad. Although Eisenhower did not commit to large expenditures, his administration's nuclear strategy was aggressive in scale and scope (Gaddiss, 2005) .However, the Cuban Missile Crisis of 1962 massively increased US citizen's engagement with civil defense education and preparedness (Dobbs, 2009, p.257). Civil defence was also criticized at times of war, primarily as part of a general pacifist movement during the latter part of the Vietnam war (1955-1975) (Garrison, 2006). Aside from the Cuban Missile crisis, the administrations of the 1960s (Kenndy, Johnon, Nixon) were less committed to the idea of a domestic 'garrison state' (Gaddis, 2005). Although these historical events are important (and are referred to in the paper, when necessary) except in dire crisis the population were largely apathetic, and a small minority hostile, to civil defence activity - including in the educational sphere (Garrison, 2006). Even the 'Red Scares of the 1950s did not move the US citizenry to civil defence activity, despite paranoia about Commuism at home and abroad. They remained 'private pacifists, but public militarists' (McEnaney, 2010).

$\mathrm{OE}$, as a part of this agency) with regard to its relationship with the civil defence authorities (the FCDA, Federal Civil Defense Administration, 1950-58, the OCDM, Office of Civil and Defense Mobilisation, 1958 - 1961, and from then on as part of the Office of Emergency Planning). Research was conducted on site at Archives II, Maryland which is one of many sites of the US National Archives. Primarily, I examined records relating to the CDAE (Civil defense adult education course), which was established in 1958, but I also refer to other, earlier, adult education initiatives.

As the data required for this research was archival there was a danger that I was only achieving a partial picture of the perspective of the OE. McCulloch (2004, pp.54-55) considers the size and unpredictability of archival resources and the dangers of inferring the content of files from the online catalogue. This was very much the case in Archives II where, unlike the extensive Discovery catalogue used by the National Archives in the UK, the online resource gave only a thin description of a file's contents. In order to gain a full perspective of the CDAE from the archives it was therefore necessary to consult all of the boxes and files concerning this initiative from the OE archives This still may have presented a partial picture. Hill (1993) refers to processes of sedimentation that occurs before documents end up in archival resources. Firstly, a choice is made by individuals and organisations about which materials to keep and which to destroy (primary sedimentation). Secondly, after the 
'death' of an individual or an organisation (or the end of a particular project) there is a further level of sedimentation in terms of triaging documents before they are passed to an archive. Finally, at the stage where documents are passed onto an archive there is a further decision about what to keep and what to destroy. There is therefore a need to account for sedimentation in terms of the validity of this research.

The fact that I did find documents which attested to conflict between the FCDA, OCDM and the OE was some evidence that primary sedimentation had been minimal. Records were sequential, consistent, and there was no evidence that records had been removed, or redacted. The internal correspondence from the OE concerning their impressions of the FCDA, and the OCDM, was sufficiently candid as to assure me that it had not been excised. Furthermore, it was evident from my time spent at Archives II that there was some anxiety amongst archivists themselves regarding whether the files I was investigating may contain materials which were 'secret' as, due to budget cuts, the majority of archives had not been sifted to remove such materials. Hence there was a strong institutional indication that records had not been removed through tertiary sedimentation (as archivists were not sure if records marked 'secret' remained). The evidence is, therefore, necessarily partial, but not necessarily invalidated through the sedimentation process. Note that when quoting from archival sources, I use American spelling where this is appropriate.

Aside from issues of sedimentation, there are other issues regarding the quality of archival evidence. Scott (1990) considers that there are four main criteria that should be used for judging the validity and reliability of archival evidence: authenticity, credibility, representativeness and meaning. The data's presence in the archive is testament to its authenticity. In terms of credibility and representativeness, it may be considered that some publications arising from the CDAE were subject to some exaggeration. As will be explained later, the civil defence authorities were engaged in a deliberate propaganda campaign to 'sell' civil defence to the population. Hence there is a risk that the reporting of material facts (such as regional CDAE initiatives) were skewed to appeal to what McCulloch refers to as the 'audience' (2011a, p.253) for policy documents. In order to deal with this issue I have drawn on a range of sources on CDAE, primarily the records of the $\mathrm{OE}$ itself but also correspondence between the $\mathrm{OE}$ and state level civil defence authorities and technical reports. This enables a more nuanced view of the meaning of the data (Scott's final criteria) and I consider both accommodations and resistances.

The conceptual framing for the data used the work of Thelen (2004). Thelen's theories of how institutions and policies evolve were developed with respect to vocational education where she introduced a nuanced model of path dependence in policy. Rather than seeing the results of a particular policy as resulting through a dialectical struggle, or as one institution achieving power over another, Thelen considers that policy can be understood through a more nuanced approach. She considers that the most important factor in determining the outcome of a particular policy is not only resistance, but also accommodation to a particular policy. That is, the extent to which the policy can be accommodated to the objectives of various institutions. Thelen does not see path dependence in policy as arising from inertia or being over-determined by executive powers. Rather it arises from the interests of institutions. These institutional objectives may not completely halt progress but rather leave it open to an accommodated settlement which can have different local results depending on institutions at the regional level. Her work is therefore useful, not only in terms of bridging the gap between history and theory (which is a more general problem in the history of education, McCulloch, 2011b), but also through rejecting a strongly determinist view of policy as driven by the sovereign state. In the case of this analysis, I examine the objectives of Federal government, and the resistances to those objectives, but I also look at the way in which accommodations were reached. In many cases, the imposition of adult education for civil defence was not countered directly, but repurposed to meet the objectives of 
the various institutions concerned. Hence I have organized the data to look at both resistances and accommodations.

In terms of the analysis of data, rather than taking the public claims of the FCDA, OCDM and other federal agencies at face value, then, (which were uniformly positive) I took an approach where I would first look for data where CDAE and related courses had been resisted at various levels. That is where objections had been raised, where there was apathy and where refusals to take part had been made. It was difficult, in fact, to find examples where OE had carried out the instructions of the FCDA directly and without reservation, but there were, as Thelen's work might indicate, cases of accommodation where the CDAE had been adapted so that it met more consistently with the pedagogical and educational objections of the OE. I will examine these categories of resistance and accommodation, but first I will consider the ways in which the FCDA initially aimed to force and influence the DHEW, and by implication the $\mathrm{OE}$, to disseminate civil defence materials.

\section{The FCDA and the DHEW: unequal partners}

The FCDA (Federal Civil Defense Administration) was established in December 1950 through the Civil Defense Act (1950). The Truman administration created the FCDA as a 'standalone' line agency of the federal government' (Grossman, 2001, 2). The Department of Health, Education and Welfare (DHEW) was formally established in 1953. However, despite being formed within a few years of each other, the power between the two bureaucracies was not equivalent. The FCDA operated as a superordinate agency of government, empowered by the direct authority of the President, and with the power to compel other government departments to provide civil defence education and facilities. The FCDA and the DHEW were, therefore, not equal partners in the relationship. The FCDA provided the DHEW with a clear executive order which would compel the DHEW to act in the FCDA's interests. The DHEW was made clear of its responsibilities under the Federal Civil Defense Act of 1950 (64 Stat, 1248). This directive set out the responsibilities of the DHEW which included specific actions with regards to education namely to:-

'Plan, develop, and distribute through appropriate channels, training materials in the curricula of schools and colleges throughout the United States in order to integrate the teaching, in all possible courses, of civil-defense skills, and knowledge and fundamentals of behavior during emergencies'.

Delegation of civil defense responsibilities to the Department of Health, Education and Welfare, $21^{\text {st }}$ January, 1954

On receiving the FCDA delegation, Assistant Secretary Mintender (of the OE) and Mr. Dean Snyder (Defence co-ordinator of the DHEW) were reported to have received the FCDA delegation and orders gladly:-

'This department is the first Federal agency to receive a delegation in the civil defense area. Mr. Mintender sees this delegation as a challenge and an opportunity for DHEW to set the pace for the whole Federal service. He underscored the fact that this is not a 'stand-by' operation, but rather a vital responsibility of the Department toward the entire population of the Nation. He expressed concern about the great apathy toward civil defense matters apparent throughout much of the country.' 
A new project resulting from the FCDA delegation was the 'Development of educational materials for civil defence for school use, which included $\$ 55,255$ for contractual services with state universities' (List of Principal DHEW projects under FCDA delegation no.1 September 29 $9^{\text {th }} 1954$ ). This included a range of civil defence programmes, not just for schools, but also adult education initiatives and other distance learning initiatives, such as educational television. The civil defence authorities also wanted to use the professional knowledge of adult educators. By 1958, the FCDA had been merged with the ODM (Office of Defence Mobilisation) to create the Office of Civil and Defence Mobilisation (OCDM) who were to develop the existing adult education courses into CDAE.

CDAE was to be the major initiative for engaging the adult population in civil defence. Instructors were trained in personal preparedness in the nuclear age, fallout preparedness family shelter design and course design (Memo to state co-ordinators of CDAE, October 26 ${ }^{\text {th }} 1962$ ). Materials used on CDAE courses included manuals for students and teachers, filmstrips and slides and short films. The students on CDAE courses would take units looking at the reasons for civil defence, purposes and objectives of the CDAE, national civil defence concepts, effects of weapons and fallout, protective measures and the effects of chemical and biological weapons (Memo to state co-ordinators of CDAE, October $26^{\text {th }}$ 1962). The model for the CDAE programme was to establish a pilot initiative and to use travelling teams of adult educators for delivery. These trainers would be instructed in CDAE principles by the civil defence authorities and would then teach three classes of $15-25$ adults each year (Memo to state co-ordinators of CDAE, October $26^{\text {th }} 1962$ ). Each trainer would be training between 45 and 75 adults for each year that they were to be contracted.

It is estimated that over three million adults took part in CDAE which was, in term of numbers, an achievement (although as I discuss below, completions were lower and some of the 'adults' were high school students). In terms of overall adult education participation in the USA this made up a reasonable fraction of overall participation over these decades as it is estimated that adult education participation each year by the end of the 1950s was in the order of 8 million (US Department of Health, Education and Welfare, 1962). CDAE can be seen in the context of the restructuring of US adult education at this time towards an increasingly instrumental ethos (in terms of serving the need of American citizenship) unlike in the United Kingdom where adult education kept a largely liberal orientation (Grace, 2011). However, whilst some states had very good coverage of CDAE, other states had no coverage at all. As CDAE developed, other courses were added such as RAMONT (Radiological Monitor Training). Shelter management was added to the curriculum in 1967, and in the same year there were funds for the development of education television courses for civil defence. Ultimately, though, funds for all of these programmes were cut back in 1969, 1970 and 1971, and on February $1^{\text {st }} 1971$, it was announced that that there would be no renewal of any CDAE programmes (The Civil Defense (Adult) Education Program, Administered by the U.S. Office of Education Civil Defense Education Branch, December 1958 - June 1971). The DHEW, facing a cut in funding, was caught unawares by the decision to stop contracting the OE in civil defence:-

'Suddenly, and without arbitration, the Office of Civil Defence has informed the Office of Education that the contract, which exists between them, will not be renewed after June 30 1971... My personal concern is one of being dominated by the Office of Civil Defence in promoting extensive training in Radiological Monitoring and Shelter Management, with little emphasis being placed on proper education for the general public and for school students' 


\section{Memo to Representative Orville Hansen from Harry Mills, Co-ordinator, Civil Defense Education.}

Despite limited protests from Commissioners of Education, this ruling effectively meant the end of the CDAE programme to be replaced with the development of new local provision, and eventually (in 1979) FEMA (Federal Emergency Management Agency) training and public information which was much less extensive than CDAE. FEMA currently holds responsibility, following on from preceding agencies, for public information and education at a Federal level, emphasizing dual use adult education, or rather public information, for both nuclear attack and other events, such as natural disasters, pandemic or terrorism.

Adult education for civil defence, at least in a formal sense, therefore lasted two decades (1950 - 1971) and spanned a number of federal agencies (primarily the FCDA and OCDM) and the DHEW as the department responsible for the delivery of CDAE. As stated above, a 'golden age' perspective on civil defence would emphasise the mobilisation of civil society and the embedding of civil defence in the consciousness and actions of the general public. However, at least in terms of adult education, the story of civil defence is very different. Rather than being fully integrated into civil society, the DHEW, states and the general public resisted the imposition of civil defence. Rather than public demand for civil defence education, Executive orders were used to create courses which were to be 'sold' to the population.

I will now turn to examine how the policies of the super-ordinate agencies were resisted and accommodated.

\section{Resistance}

\section{The impact of executive orders}

The DHEW were resistant to the anti-democratic and non-consultative way in which earlier adult education efforts and the CDAE were imposed upon them by Executive order. Executive orders are issued by the President of the United States to enable the management of Federal Authorities. They are not strictly constitutional, and are used in states of emergency. Executive orders were used to grant the FCDA the power to direct the work of the DHEW towards civil defence. In a FCDA advisory bulletin (FCDA Advisory Bulletin, no.175, September 17, 1954), informing a delegation of the FCDA to the DHEW, the FCDA laid out the extent of their powers:-

'Under today's delegation, the Executive agencies assume responsibility for specific civil defense problems directly related to their day to day work..This program is directed by the Federal Civil Defense Act of 1950, Public Law 920 (64, Stat.1248). The Act authorizes the FCD Administrator to 'delegate, with the approval of the President, to the several departments and agencies of the Federal Government appropriate civil defense responsibilities, and review and coordinate the civil defense activities of the departments and agencies with each other and with the activities of the states and neighboring countries'.

Notably, the FCDA, had an executive power not only over the DHEW, but over all other government departments in terms of their civil defense responsibilities. On April 28, 1955, the office of the administrator of the FCDA (Val Peterson) issued a:- 
'...draft of a proposed Executive Order establishing the Civil Defense Coordinating Board. The purpose of the Civil Defense Coordinating Board is to provide the maximum coordination of effort throughout the Executive Branch in matters relating to the civil defense of the Nation'.

\section{Draft of Executive Order from the office of the administrator of the FCDA, April $28^{\text {th }} 1955$}

These emergency powers were extended by other directives over subsequent years. According to later documents (Federal Register of January 24th, 1961 Executive Order 10773) additional powers were provided to the OCDM, relating to all conditions of "national emergency".

At least publicly, the DHEW gave the impression that it was in favour of these powers, and would act with the civil defence agencies to achieve them. For example, in publicity material for the CDAE, it was considered by Arthur S. Flemming, Secretary of Health, Education and Welfare, that his agency were largely motivated to take on board civil defence education plans:-

'This timely Civil defense adult education effort deserves the active interest and support of all thoughtful persons. I hope, especially, that the people who make up the official family of the Department of Health, Education and Welfare will do what they can to help this program attain its objectives. This is the kind of preventive service in which we-among all agencies of government-should excel'

\section{Civil Defense Education Newsletter, Number 3, May 1960}

In some interpretations of this type of evidence (Grossman, 2006) this would strongly indicate that the central government was imposing, in an authoritarian fashion, its will on the education department. This analysis, though, needs to consider how, in turn, the education department reacted at an institutional level. In fact, despite this glowing assessment, there was some initial resistance in the Department of Health, Education and Welfare to the FCDA's demands. Following the first visit of the FCDA to the DHEW, a 1954 memoranda from Commissioner Brownell, of the Office of Education (Meeting with Official of Federal Civil Defense Administration on Relation of Education to Civil Defense, 1954), considered that the scope of the FCDA's remit would leave little else for the OE to do which was not concerned with civil defense:-

'...the current proposal is far from adequate. Among the areas of responsibility which appropriately might be delegated by FCDA to the Office of Education are these: 1. Planning for the transportation and care of the school population in the event an evacuation of a community is ordered. 2. Training of students, faculty and staff in personal and property protection procedures. 3. Preparation and distribution of materials of instruction concerning protective citizenship concepts for use in the schools and college. 4. General assistance in the training of personnel for civil defense activities. 5. Planning, in collaboration with FCDA, the general policy concerning the utilization of educational facilities in an emergency situation'

Dean Attlee Snyder, in an attempt to soften the objections of the OE considered that Commissioner Brownell may be more considerate of the FCDA's demands if they were to recognise the expertise of his department, particularly in terms of new forms of protective citizenship. The outcome of this was some willingness to meet the DHEW's demands and a new set of responsibilities (Delegation of civil defense responsibilities to the DHEW, $21^{\text {st }}$ January, 1954) that included largely school based obligations to:- 
'Plan program and issue technical guidance to the States and cities concerned with the provision of shelter and other safety measures designed to protect school children in the emergency and prepare and issue training devices to be incorporated in the public school curricular for the purpose of education students, and through them their parents, in fundamentals of behaviour during the emergency.'

This was still not sufficient for the OE who considered that the FCDA were trying to impose increasingly onerous activities on them. The FCDA's nuclear holocaust scenarios became increasingly apocalyptic and called for universal and intensive civil defence education The OE considered that:-

'The Office of Education has 2 primary civil defense responsibilities: (1) The preparation of teaching materials and (2) the drafting of protective measures for schools. The office of Education has signed agreements with State Departments of Education in Connecticut, Michigan and California for the purposes of establishing pilot centers which will prepare the instructional guides and handbooks for teachers. Dr. Brownell referred to the great difficulty in developing teaching materials since the basic assumption as to the type of attack and its consequences are continually being changed.'

\section{Meeting on February 17, 1955: Progress report on HEW Civil Defense Planning}

As the above evidence shows, the FCDA, and latterly the OCDM, were given super-ordinate powers by Executive orders to impose their plans for civil defence on the DHEW. These powers were extensive, but the OE of the DHEW was able to resist some of these powers, or at least reduce some of the impact of the initial Executive orders. The institutional level analysis shows that there is some resistance, to a 'militarisation' of US society.

\section{Resistance of States}

As well as national institutions, Thelen's (2004) analysis of institutional and policy development also considers regional and local accommodations. This is also the case in terms of the CDAE. The three areas chosen for the launch of the adult education pilot programme that eventually became CDAE, California, Connecticut and Michigan, were provided with civil education materials that emerged from the OE. Following the establishment of the "Office of Education Civil Defense Education Project" in January 1955 (Civil Defense Education Project Information Sheet, January $24^{\text {th }}, 1955$ ), by July 1955 , (Office of education, civil defense education project progress report number 9, July $15^{\text {th }}, 1955$ ) the OE had distributed materials on a basic civil defence course for adults, questions and answers on fallout, requirements of school shelter facilities, civil defence protection of vital school records, a document called 'The problem of panic' and a checklist on civil defence in schools. The penetration into schools was potentially extensive and required a 'whole school approach' involving not only education of the children but also training of nearly every adult working in the school, giving obligations to the school administrator, instructors, school's community relations program officers, the school nurse, the school engineer / custodian (caretaker) and even the school bus driver to make preparations for civil defence (Civil Defense Education Project Information Sheet, number 29, July $21^{\text {st }} 1955$ ).

The training for adults, did not meet without opposition and even at an early stage Californian officials considered that there were legal problems with the Federal government encroaching into the education of the state. Indeed, when it was felt that the OE was overstepping its remit, and infringing on the civil 
liberties of citizens, states were quick to protest. For example, a 1955 information sheet (Civil Defense Education Project, Information Sheet No.20, May $9^{\text {th }} 1955$ ) proposed the wearing of an identification tag system for all citizens so that they could be identified more easily following a nuclear attack:-

'...a metal tag attached to a necklace, or bracelet to be worn permanently around the neck, wrist or ankle which would contain the name of wearer, next of kin, address of next of kin and potentially blood type and religion.'

However, at a local level, there was opposition to such a move, preferring 'local determination' (California), decision making by 'community groups' (Delaware) and 'school and community groups' (Kentucky) (Civil Defense Education Project, Information Sheet No.20, May $9^{\text {th }} 1955$ ).

State objections continued as CDAE was extended beyond the original three states. Alabama, Arkansas, Arizona and North Carolina agreed to participate, six other states held off participation until they had consulted with their local school boards or legislatures. Two states refused to participate at all (Progress Report on the Civil Defense Adult Education Program, October 30 ${ }^{\text {th }}, 1962$ ).

It was only through the Cuban Missile Crisis that the CDAE programme received some attention by states but:-

'Prior to the Cuban Missile Crisis, reports from many states indicated current widespread disinterest in civil defense education and told of difficulty in the organisation of classes and retention of enrollees through the whole course...Since precipitation of the Cuban crisis, disinterest in civil defense education has been replaced by unprecedented interest.'

Progress Report on the Civil Defense Adult Education Program, October 30 ${ }^{\text {th }}, 1962$.

Aside from this crisis, there was little interest in undertaking CDAE although there was some evidence that those people who did participate did undergo some personal transformation. An evaluation ('Civil defense adult education Program Study' of 11 October 1968 by the System Development Corporation, Santa Monica, California) considers that the program was 'effective' and that:-

'The statistical analysis (by Chi-Square) of the PFS Student Questionnaire responses revealed many statistically significant differences among the population and time variables. The conclusion drawn is that there are indeed changes in civil defense attitudes, knowledge and actions taken due to the impact of the PFS course.'

This was not a National analysis, and it was undertaken in Alabama, California, Massachusetts, Minnesota, Missouri and Oklahoma only: states that were reasonably positive about CDAE. However, many states were not convinced of the economic or governance case for the continuation of the CDAE program. Although there was some take up by states such as Alabama, North Carolina and Oklahoma in the 1960s, fueled by the Cuban missile crisis, by 1970 many states were openly critical of the CDAE programme. In a file marked 'criticism' (OCD Survey, October $\left.23^{\text {rd }}, 1970\right)$, from an OCDM survey, there is open criticism of the OE's CDAE programmes in terms of autonomy, cost and inefficiency from state civil defense planners.

Firstly, in terms of the OE's power over states, the comment from Alaska states that the idea of a 'mutually accepted state plan' regarding CDAE is a misnomer as, in terms of willingness to 
compromise: "The Office of Education demonstrated no such willingness". Comments from Kansas also consider the problems of co-ordination between Federal government and states.

Secondly, the expense of the program is considered. Comments from Idaho state that the program is a

‘...terribly expensive luxury item we should eliminate or modify due to present overall budget limitations. In the interest of economy and efficiency, I urgently recommend that the Civil Defense Education Program be contracted and administered by the Idaho Department of Disaster Relief and Civil Defense.'

This comment was echoed in Kansas where it was considered that:-

'Ever since the inception of both the CDAE...(and other)...contract programs, we have felt strongly that if the equivalent amount of Federal funds involved in these contracts was made available to this office, we could do a far better job, solely because these programs would be provided with centralized control.'

In Montana, it was considered that the central government should '.. retain the funds that are administered to the Office of Education and consequently save the high cost involved.' Wyoming considered that '...we are not receiving adequate results for the monies expended'

Thirdly, the negligible impact of the program on the general public was considered. Arkansas commented that 'I don't feel that the CDAE program is making any significant headway... At this time, I cannot think of any place here in the state where the CDAE program has made any impact', Michigan commented that '...communities are losing interest in Civil Defense', and Rhode Island that the "program has been ineffective". Wyoming gave a simple two word answer: 'Minimal impact'. Most cynically, Michigan considered that the real audience for the project was not the general public at all, but rather to meet the requirements of bureaucrats and 'We believe that the progam is having an impact on captive audiences in state government'. As this analysis shows, it is not just institutions at a national level, but also regional bodies that opposed CDAE.

\section{Patchy and low take up of civil defence education}

Whilst not a complete failure, CDAE did not meet the expectations of the original plans and was very patchy in terms of take up amongst states. The OE was very aware that civil defence education was not particularly demanded by the general population, and needed to be sold to the public. Whilst the general public was largely not opposed to civil defence (aside from some small yet very active protests) they were relatively passive and disinterested in the concept. It was considered that public resistance was something that could be overcome with strong sales techniques. Consumer marketing was in its infancy, and a strong sales orientation still dominated perceptions of how to 'shift' a product or service. In a presentation to the CDAE seminar on February 20th, 1964, the civil defence representative from the OCDM pushed the message that "CDAE" should be spelt out as "S-E-L-L" (CDAE conference, June 1964). The public would need to be persuaded concerning the need for civil defence:-

'Every new product gains acceptance thru promotion and salesmanship. Public lack of interest, apathy, lack of confidence and belief in the product must be overcome. In the case of the CDAE program it meets resistance because of these and other reasons. So the "selling techniques" become an important factor in making the program go. Perhaps we should sell 
"Personal Survival" rather than "Civil Defense". Whatever the image created in the public mind it will take salesmanship to put it across.'

In terms of the 'selling' of CDAE, rather than concentrate on numbers, which were often embarrassingly low, the CDAE program was promoted and reinforced through case studies of successful interventions. These 'story' narratives (Memo from director civil defense education of the US office of education to state co-ordinators of CDAE, January $6^{\text {th }}, 1963$ ) were considered to be 'specific, impressive and, we believe, representative of what is happening everywhere ODAE classes are held'.

This was hyperbole, and the CDAE was certainly not a success 'everywhere'. On a national scale, the figures for the course initially appear impressive. Between October 1959 and December 1970, 3,125,674 courses were completed. However, not all of these completions were CDAE adults. 90,581 of this number were PFS teachers and nearly a million $(868,250)$ were high school students. This means, in actuality, just over 2 million adults completed CDAE. (The Civil Defense (Adult) Education Program, Administered by the U.S. Office of Education Civil Defense Education Branch, December 1958 - June 1971). The RAMONT and shelter management courses did not add much to this total, with 158,895 trained in Radiological Monitoring and 31,504 in shelter management training (The Civil Defense (Adult) Education Program, Administered by the U.S. Office of Education Civil Defense Education Branch, December 1958 - June 1971). Given a total US adult population (over 18) of 136 million in 1970, this means that around $1.5 \%$ of the population had received CDAE training. A small proportion of the adult population had therefore completed a personal survival programme. The reported number of trained adults to instructors was approximately 35, which was below the (minimum) 45 students who were targeted for instruction each year, and way below the maximum number (75).

Once these overall figures are disaggregated to states, there are massive variations. Completions per. 100,000 adults in 1970 for the Personal and Family Survival course (which is a very minimal definition of what adult education in civil defence might involve) were excellent, and perhaps a subject to overcounting (as all state employees in some areas were provided with minimal civil defence training) in Pennsylvania $(50,787)$, Illinois $(46,589)$ and Texas $(40,591)$ but lousy in New York (5) and Rhode Island and non-existent in Delaware (0). Cumulative completions from 1959-1970 were also very poor for some states, particularly Rhode Island (130) and New York (63). So when looking at the aggregate figures it must be remembered that there are significant variations between states. Some had excellent completion rates, in others completions were virtually non-existent.

However, as suggested above, participation in CDAE at least increased in a perceived crisis. In 1962, the Cuban Missile Crisis increased enrollments:-

'The CDAEP is now being developed in 35 states, the District of Colombia and Puerto Rico. Although school activity slows down during the summer months, over 5,000 teachers and adults completed the Civil Defense Course during July, Moreover, information from the States indicated that approximately 10,000 adults would be attending classes during the month of August.'

Memo to Herman L. Offner, Director, Office of Field Services from Neil W. Ackland, Director, Civil Defense Education staff, September 131962 
However, there is a difference between enrollments and completions and a quarter of those who enrolled in CDAE during the Cuban Missile Crisis did not complete as tensions died down. By November $1^{\text {st }} 1963$ the Cuban Missile effect had completely worn off:-

'...detailed analysis of the monthly reports submitted by States showing little or no progress during recent months has been made and priorities assigned for the concentrated effort of this staff to provide guidance, assistance and stimulation to members of the State Staffs'

Memo to Herman L. Offner, Director, Office of Field Services from Neil W. Ackland, Director, Civil Defense Education staff, May 5, 1964

As the above shows, the idea of a 'civic garrison' (Grossman, 2006) did not apply widely across the United States. Although there may have been localized areas where CDAE was accepted, for the most part the population was indifferent.

\section{Accommodation}

That CDAE managed to survive at all in the DHEW was largely due to the OE's ability to accommodate, to a certain degree, the demands of the civil defence agencies particularly given the large quantity of funding that was offered for conducting CDAE programmes. The OE was able to accommodate civil defence within its professional and institutional interests in various ways.

Congruent with Thelen's analysis of 'path dependence' in policy, these accommodations altered the direction of CDAE in subtle ways.

\section{New models of 'protective citizenship'}

The OE was able to meet the requirements of the FCDA and its successors by aligning this initiative with its thinking on the social outcomes of education. In particular, the OE was aiming to produce new forms of citizenship, compatible with a post-war welfare system. This was the notion of "Protective Citizenship" a concept which gave the citizen responsibility and agency for their economic and physical protection. They were able to slip this concept into the FCDA directives imposed upon them. For example, the Office of Education considered that it had the remit to:-

a. Continue to assist FCDA in developing training materials and plans. Much assistance already given, but large numbers of registered CD workers are still untrained. If their interest is to be maintained, training programs must be developed and implemented.

b. School protection programs (e.g., shelters, rescue training, etc.)

c. Integration into curricular of civil defense (including natural disaster) concepts - in educational terms this is 'protective citizenship'

Civil Defense Briefing given by the Department of Health, Education and Welfare, January 13, 1954, my italics

Similarly, the OE was able to devise its own pedagogical strategies for delivering civil defence education. As stated above, it was able to use 'school wide' strategies by including different members of staff within schools and, as will be discussed below, it was able to make use of new educational 
media. Therefore, in softening the blow of executive power by the FCDA and the OCDM, the OE was able to promote some of its own educational values, promoting 'protective citizenship' through the funds provided by the civil defence agencies. As well as resistance then, the OE did find some reasons to make progress with CDAE.

\section{New media (educational television)}

Thelen's (2004) analysis of vocational education downplays the notion of technological change in favour of institutional development and progression. However, in this analysis the two were found to be linked as the $\mathrm{OE}$ was also able to use the funding gained to experiment with new modes of education. There was some consensus, both in the civil education agencies and in OE, that personal and family survival could be taught through educational television. This involved not just using television as a straight forward broadcast medium, but by introducing elements of interactivity in what were called 'telecourses'. The Division of Vocational and Adult Education (General Adult Education section) of the OE created a study guide and television series for CDAE called 'Personal Survival in Disaster'. The booklet designed for the series (or 'telecourse' as it is called on pg ii in the booklet) states that viewers should not only view for personal use but also:-

'Make a family activity of viewing Personal Survival in Disaster, The entire family is involved and, therefore, each member should know what to do in case of disaster. Make every effort to join a local discussion group in Personal Survival in Disaster'. The programs include 'Introduction to Nuclear Explosions', 'Family fallout shelters', 'Role of government in disaster' and 'Community survival plan'

Personal Survival in Disaster, April $6^{\text {th }}, 1961$

The telecourse contained such questions as 'Is radiation sickness contagious?', 'What are some problems that might be found in our post attack economy?', and 'In developing a school disaster plan, what is the role of the school, of the parent'.

The general principles of 'telecourses' were used to create a number of pilots for civil defence for adults through educational television. The early pilots were not successful. In 1963, OCDM contracted with Louisiana State to produce a CDAE course for TV. Pilots are mentioned in this (undated) memo from the same period:-

'California, Florida, Minnesota and Texas civil defense adult education staffs (sic.) attempted it in the early days of CDAE. Although these were noble efforts, the presentations were not professional, either in content or technologically. There was no real evidence that they accomplished much,

\section{TV Projects for Civil Defense Adult Education, undated memo}

However, later efforts were more productive. In Maine, an eight program television series called 'Personal and Family Survival Program' presented by the Maine State Dept of Education in Cooperation with the Maine Civil Defense and Public Safety Agency, Augusta, Maine' was created in 1967. This featured television programs which covered such themes as "Living in the twentieth century", "A Do-It-Yourself Experiment in Survival Living" and "Nuclear War...and then what?" The scripts are based around an 'ordinary' Maine family. According to the script from programme one, the 14 
characters would be:-

'Ben Rogers (Roy Mercier) - Down-to-earth, friendly, neighborly fellow, owner of local hardware store, civic-minded, likes to talk, always casually smoking a pipe', his wife Alice 'warm, sincere, hospitable, active in PTA', Susan Rogers 'Teenager (17) pretty and popular, dresses in latest teen fashion, mostly interested in boys', Bobby Rogers 'active, adventurous, curious, alert 7 year old, quite imaginative' Madge Owens 'Friend of Alice Rogers, civic minded' and Squirt, 'Roger's blonde cocker spaniel'.

\section{Maine TV Program, 1967-1968}

As the below quote suggests there were even attempts to make Civil Defence something that would resonate with teen culture in the 1960s:-

'Well, Susan was just bursting with news about the new Civil Defense instructor who was coming to the high school every two weeks to present a course in Personal and Family Survival. Believe me, Susan wasn't all that excited about the course. It was the instructor. He was 'really neat' as Susan put it...'just dreamy, sort of like Rock Hudson, James Bond and the Beatles all rolled into one'. Susan, along with Betsy Owens and Karen Mitchell had stayed after school to talk to the teacher and so had missed the school bus and ended up walking home. Well, apparently this guy was really 'with it.' As Susan put it, 'they were learning to play it cool, how to fake out this bomb jazz, and like how to beat the bomb, man'...rough translation...how to be prepared, know what to do in the event of nuclear explosion, and how to protect yourself from fallout.'

Maine TV Program, 1967 - 1968

An interactive telecourse was also broadcast in Massachusetts:-

'Man's prospects for survival and protection in the nuclear age will be evaluated when 'A Matter of Concern' begins on WBGCX-TV, Channel 44, Wednesday, February 7th at 8pm. Combining documentary technique with discussion, the series presents facts and fallacies about atomic energy and offers viewers an opportunity to talk with the experts via telephone during the program.'

Flyer, News from WGBX-TV 44, $17^{\text {th }}$ Jan, 1968

The telecourse invited people to phone in and notes were taken concerning topics of viewer interest. Texas also ran a Civil Defence TV project, entitled 'Emphasis Survival' with 30 minute programs shown over 15 weeks. The telecourses allowed the OE to experiment with reaching new demographic groups for civil defence and also interactivity, whether this was through a workbook or phone-ins. It must also be noted that there was some glamour and excitement associated with the use of television by the $\mathrm{OE}$ and civil defence authorities. Indeed, one photograph in the archives is of (unidentifed) OE officials in Hollywood mode, proudly holding a spool of film. Educational technology was, therefore, one way in which the $\mathrm{OE}$ accommodated the needs of the central government.

\section{Demonstration of expertise}


In order to accommodate the responsibility for civil defence, the OE wished to retain its role as the experts in matters relating to education and pedagogy. The initial agreement between the FCDA and the OE placed the FCDA in the lead role in terms of expertise, with responsibility for developing materials to be a wider responsibility. In this model, the FCDA would provide the basic structure, with education professionals (not necessarily the $\mathrm{OE}$ ) providing the curriculum expertise. The $\mathrm{OE}$ in the DHEW was keen, however, to demonstrate its pedagogical expertise in civil defence education matters and it extended its remit to:-

'Provide professional educational advice and guidance to the Federal civil defense administration, and to any Government department or agency to whom civil defense responsibilities are delegated, in the development and operation of training programs, including the preparation of training materials'

Office memorandum to Rusell R.Larson, Assistant Secretary, from Wayne O.Reed, Assistant Commissioner, division of state and local school system, May $6^{\text {th }} 1954$

This expertise of the OE was emphasized in subsequent correspondence:-

'From the inception of the OE Civil Defense Education Project, it has been our understanding that FCDA would supply the Office for Education through basic assumptions, criteria and standards for the determination of administrative policies. We have not understood, and do not accept the position that various FCDA technical services retain supervisory responsibility at the operation level (underlined) over OE activities.'

Letter from Commissioner Brownwell to Dean Snyder and John R Luddington, Chief Civil Defence Education Project, March $25^{\text {th }} 1955$

The expertise of the $\mathrm{OE}$ in refining and evaluating materials was also aired in official enquiries into civil defence:-

'A knowledge of civil defense and of personal and family survival measures in an emergency must be 'built-in' to the thinking of all of our people....emphasis will be placed upon the refinement, testing and evaluation of the teaching materials developed.'

Statement by Bradshaw Mintener, Assistant Secretary of Health, Education and Welfare before a Committee on appropriations, 1956 estimates - civil defense activities, Department of Health, Education and Welfare.

Hence it can be seen that the $\mathrm{OE}$ was keen to constantly position itself as being the 'expert' department in educational matters, with a clear focus on its expertise, and institutional distinctiveness, from the FCDA and the OCDM. Recognition of this expertise made it easier for the OE to comply with the demands placed upon it and reduce institutional inertia.

\section{Conclusion and future lessons}

This was certainly not quite the 'Golden age' of education and security in terms of the attitude of the OE, the states and the patchy and sparse take up of adult education. However, neither was it a complete failure of civil defence education for adults. The resistance of the OE was more in terms of 
keeping their credibility as experts than flatly rejecting civil defence education (which would have, in any case, been unlikely given the use of Executive orders). Rather the OE produced, to the best of its ability, a version of CDAE which would also satisfy its intellectual and expert ambitions. It developed a version of protective citizenship, 'telecourses' and was vocal about its integrity in terms of educational expertise. Using Thelen's (2004) work on institutional path dependence is a congruent conceptual framework for considering the progression of CDAE policy. Rather than the exercise of, or opposition to, centralized power, the CDAE morphed into a very different formation than the central government first supposed. Where the CDAE was accommodated, it was in areas that met the objectives of the OE. This is a very different analysis from one which would consider the US to be a 'civic garrison' (Grossman, 2006) during this time. In terms of structure and agency, it shows that educators (and learners) can accommodate and resist seemingly intractable security directives, and assert some kind of power. Indeed, recent work has considered that one of the major lessons of civil defence in the United States was the difficulty of imposing a national programme whilst recognizing the success of some initiatives at state level (Roberts, 2011).

To place this in contemporary context, in terms of the current concerns of FEMA, and other agencies, in terms of educating adults to prepare for contemporary emergencies (Preston, 2009) there is no 'golden age' to return to. Adult education was not demanded by the American public in the cold war and looking back to this era in terms of preparing for the (so called) 'war on terror' is instructive in that it offers lessons in failure (or at least lukewarm achievements), rather than in success. Even if directed by Executive authority, using emergency powers, things do not appear quite as expected. Resistances at various levels of the chain of educational production (Federal organisations, states, individual apathy), and creative accommodation, produces an adaptive sequence of events that is far from a linear process of curriculum planning. Adding to this uncertainty, adult learners frequently interpret government emergency communications in unexpected (and often insightful) ways (Preston, Avery, Chakrabarty and Edmonds, 2011). The best way of summing up the direction of Homeland Security adult education is in Donald Rumsfeld's infamous dictum of a 'known unknown'. Things will happen

(given the executive authority of an agency like FEMA) but what it will look like cannot be determined in advance and depends on the counter-veiling forces of educational agencies across different levels.

\section{Acknowledgements}

This work was supported by the ESRC under grant number ES/K000233/1

\section{References}

Note that for references from the National Archives of the United States I have used the referencing procedure specified by the National Archives and Record Administration General Leaflet 17 'Citing Record in the National Archives of the United States'

Ball,S. (2006) Education Policy and Social Class (London, Routledge)

Bassnett,A., Noble,A. and Phu,T. (2015) Cold war visual alliances, Visual Studies, 30,2.119-122.

Brown,J. (1988). 'A is for Atom, B is for Bomb': Civil Defence in American Public Education: 19481963, Journal of American History, 75, 68-90.

CDAE conference, June 1964, Container 1 Civil Defense Adult Education Progress Reports, 1961 - 
1963 THRU conferences, 1964 - 1965, Department of Health, Education and Welfare (DHEW), Office of Education, Bureau of Adult Vocational and Technical Education, Division of Adult Education Programs, Civil Defense Education Branch (OE CD records), Record Group (RG) 12, National Archives II, College Park, University of Maryland (NACP).

Civil defense adult education Program Study of 11 October 1968 by the System Development Corporation, Santa Monica, California, Container 5: DHEW, Civil Defense Education., civil defense subject files; 1959 - 1971. Evaluators Committee Meeting, 1969 THRU Maine TV, 1967 - 1968, Department of Health Education and Welfare, OE CD records, RG 12, NACP.

Civil Defense Education Newsletter, Number 3, May 1960, Container 2: Conferences, 1966 - 1970 (8 folders) THRU Correspondance with states - letters of protest 1968 - 71, Container 2: Conferences, 1966 - 1970 (8 folders) THRU Correspondence with states - letters of protest 1968 - 71, DHEW, OE CD records, $\mathrm{RG} 12$, NACP.

Civil Defense Education Project Information Sheet, January $24^{\text {th }}, 1955$, Book R: Records Of Dean Snyder, FCDA Delegations To DHEW - Goals, Reports And Miscellaneous - Office Of Defense Coordinator, 1954 - 55, files of Dean Atlee Snyder, 1940 - 1958, General records of the DHEW,19351981, RG 235, NACP.

Civil Defense Education Project Information Sheet, number 29, July $21^{\text {st }} 1955$, Book R: Records Of Dean Snyder, FCDA Delegations To DHEW - Goals, Reports And Miscellaneous - Office Of Defense Coordinator, 1954 - 55, files of Dean Atlee Snyder, 1940 - 1958, General records of the DHEW,19351981, RG 235, NACP.

Civil Defense Education Project, Information Sheet No.20, May $9^{\text {th }} 1955$, Book R: Records Of Dean Snyder, FCDA Delegations To DHEW - Goals, Reports And Miscellaneous - Office Of Defense Coordinator, 1954 - 55, files of Dean Atlee Snyder, 1940 - 1958, General records of the DHEW,19351981, RG 235, NACP.

Collier,S. and Lakoff,A. (2008) The vulnerability of vital system: How 'Critical Infrastructure' became a security problem. In K.Cavelty and K.Kristensen (eds.) Securing 'the Homeland': Critical Infrastructure, risk and security (London, Routledge).

Delegation of civil defense responsibilities to the Department of Health, Education and Welfare, $21^{\text {st }}$ January, 1954, Book Q: records of Dean Snyder, Defense Delegations, FCFA / DHEW, 1953 - 54, Files of Dean Atlee Snyder, 1940 - 1958, General records of the DHEW,1935-1981, RG 235, NACP. Delegation of civil defense responsibilities to the DHEW, $21^{\text {st }}$ January, 1954, Book Q: records of Dean Snyder, Defense Delegations, FCFA / DHEW, 1953 - 54, files of Dean Atlee Snyder, 1940 - 1958, General records of the DHEW,1935-1981, RG 235, NACP

Department of Health, Education and Welfare', Office of the Secretary, October $6^{\text {th }} 1954$, Book Q: records of Dean Snyder, Defense Delegations, FCFA / DHEW, 1953 - 54, Files of Dean Atlee Snyder, 1940 - 1958, General records of the DHEW,1935-1981, RG 235, NACP

Dobbs,M. (2009) One Minute to Midnight (Arrow, London).

Draft of Executive Order from the office of the administrator of the FCDA, April $28^{\text {th }} 1955$, Book R: 18 
Records of Dean Snyder, FCDA delegations to DHEW - goals, reports and miscellaneous - office of defense coordinator, 1954 - 55, files of Dean Atlee Snyder, 1940 - 1958, General records of the DHEW,1935-1981, RG 235, NACP.

FCDA Advisory Bulletin, no.175, September 17, 1954, Book Q: records of Dean Snyder, Defense Delegations, FCFA / DHEW, 1953 - 54, files of Dean Atlee Snyder, 1940 - 1958, General records of the DHEW,1935-1981, RG 235, NACP

Federal Register of January 24th, 1961 Executive Order 10773, Container 2: Conferences, 1966 - 1970 ( 8 folders) THRU Correspondance with states - letters of protest $1968-71$, Container 2: Conferences, 1966 - 1970 (8 folders) THRU Correspondence with states - letters of protest 1968 - 71, DHEW, OE CD records, RG 12, NACP.

Fisher.R. (2010) The Golden Age of BTEC: the business education curriculum in 1980s Further Education, The Curriculum Journal, 14, 2, 253-277.

Fosher,K. (2010) Under Construction: Making Homeland Security at the local level, (Chicago: University of Chicago Press)

Garrison,D. (2006) Bracing for Armageddon: why civil defense never worked (Oxford, Oxford University Press).

Grace,A (2011) Building a knowledge base in US academic adult education. In S.Merriman and A.Grace (eds) The Jossey-Bass Reader on Contemporary Issues in Adult Education (San Fransisco: Jossey-Bass).

Grossman,A. (2001). Neither Dead Nor Red (London, Routledge)

Hill,M. (1993). Archival Strategies and Techniques (London, Sage)

Hofstadter,R. (2008) The Paranoid Style in American Politics (London, Vintage Editions).

Kuklick,B. (2009) A political history of the United States: One Nation Under God

(Basingstoke:,Palgrave).

List of Principal DHEW projects under FCDA delegation no.1 September 29 ${ }^{\text {th }} 1954$, Book Q: records of Dean Snyder, Defense Delegations, FCFA / DHEW, 1953 - 54, Files of Dean Atlee Snyder, 1940 1958, General records of the DHEW,1935-1981, RG 235, NACP

Maine TV Program 1967 - 1968, Container 5: DHEW, Civil Defense Education., civil defense subject files; 1959 - 1971. Evaluators Committee Meeting, 1969 THRU Maine TV, 1967 - 1968, DHEW, OE CD records, RG 12, NACP.

McCulloch,G. (2004) Documentary Research in Education, History and the Social Sciences (London, Routledge Falmer)

McCulloch,G. (2011a) Historical and documentary method in education. In L.Cohen, L.Manion and K.Morrison, Research Methods in Education (Abingdon: Routledge). 
McCulloch,G. (2011b) The Struggle for the History of Education (Abingdon: Routledge).

McEnaney,J. (2010) Cold War mobilization and domestic politics: the United States. In M.Leffler and O.A. Westad (Eds.) The Cambridge History of the Cold War (Cambridge: Cambridge University Press).

McEnaney,L. (2000). Civil Defense Begins at Home: Militarization meets everyday life in the fifties. (Princeton NJ, Princeton University Press)

Meeting on February 17, 1955: Progress report on HEW Civil Defence Planning, Book R: Records Of Dean Snyder, FCDA Delegations To DHEW - Goals, Reports And Miscellaneous - Office Of Defence Coordinator, 1954 - 55, files of Dean Atlee Snyder, 1940 - 1958, General records of the DHEW,19351981, RG 235, NACP

Meeting with Official of Federal civil defence administration, 1954, on Relation of Education to Civil Defence, Book Q: records of Dean Snyder, Defense Delegations, FCFA / DHEW, 1953 - 54, files of Dean Atlee Snyder, 1940 - 1958, General records of the DHEW,1935-1981, RG 235, NACP

Memo from director civil defense education of the US office of education to state co-ordinators of CDAE, January $6^{\text {th }}, 1963$, Container 1 Civil Defense Adult Education Progress Reports, 1961 - 1963 THRU conferences, 1964 - 1965, DHEW, OE CD records, RG 12, NACP

Memo to Herman L. Offner, Director, Office of Field Services from Neil W. Ackland, Director, Civil Defence Education staff September 13 1962, Container 1 Civil Defense Adult Education Progress Reports, 1961 - 1963 THRU conferences, 1964 - 1965, DHEW, OE CD records, RG 12, NACP.

Memo to Representative Orville Hansen from Harry Mills, Co-ordinator, Civil Defense Education, Container 2: Conferences, 1966 - 1970 (8 folders) THRU Correspondence with states - letters of protest 1968 - 71, DHEW, OE CD records, RG 12, NACP.

Memo to state co-ordinators of CDAE, October $26^{\text {th }} 1962$, Civil Defense Adult Education Project Reports 1964-1968, Box 1, DHEW. Office of Education. Bureau of Adult, Vocational and Technical Education. Division of Adult Education Programs. Civil Defense Education Branch. RG 12, NACP. News from WGBX-TV 44, $17^{\text {th }}$ Jan, 1968, Container 6: DHEW, Office of Education, Civil Defense Education. Entry A1 45 subject files 1959 - 1971, Massachusetts TV program, 1967 - 1968 THRU fiscal and statistical data on contracts, 1964 - 70, Department of Health Education and Welfare, OE CD records, RG 12, NACP.

OCD Survey, October 23 ${ }^{\text {rd }}, 1970$, Container 2: Conferences, 1966 - 1970 (8 folders) THRU Correspondance with states - letters of protest 1968 - 71, DHEW, OE CD records, RG 12, NACP

Office memorandum to Rusell R.Larson, Assistant Secretary, from Wayne O.Reed, Assistant Commissioner, division of state and local school system, May $6^{\text {th }} 1954$, Book Q: records of Dean Snyder, Defense Delegations, FCFA / DHEW, 1953 - 54, files of Dean Atlee Snyder, 1940 - 1958, General records of the DHEW,1935-1981, RG 235, NACP

Office of education, civil defence education project progress report number 9, July $15^{\text {th }}$, 1955, Book R: 20 
Records Of Dean Snyder, FCDA Delegations To DHEW - Goals, Reports And Miscellaneous - Office Of Defence Coordinator, 1954 - 55, files of Dean Atlee Snyder, 1940 - 1958, General records of the DHEW,1935-1981, RG 235, NACP.

Personal Survival in Disaster, April 6 ${ }^{\text {th }}$, 1961, Container 17 Snyder, Dean (DHEW, Defense Coordinator), Correspondence, 1959 - 1962 THRU Educational Television, 1966, files of Dean Atlee Snyder, 1940 - 1958, General records of the DHEW,1935-1981, RG 235, NACP.

Preston, J. (2009). Preparing for Emergencies: citizenship education, whiteness and pedagogies of security, Citizenship Studies, 13, 187- 200.

Preston,J. (2012). Disaster Education (Rotterdam, Sense Publishers)

Preston,J., Chadderton,C.and Kitagawa,K. (2014) "The 'state of exception' and disaster education: a multilevel conceptual framework with implications for social justice," Globalisation, Education and Societies, 12, 3, 1-20.

Preston,J.; Avery,B.; Chakrabarty,N. and Edmonds,C. (2011). Emergency preparedness as public pedagogy: the absent presence of race in 'Preparing for Emergencies', International Journal of Lifelong Education, 30, 749-762.

Progress Report on the Civil Defense Adult Education Programme, October $30^{\text {th }}, 1962$, Container 2: Conferences, 1966 - 1970 (8 folders) THRU Correspondance with states - letters of protest $1968-71$, DHEW, OE CD records, RG 12, NACP.

Roberts,P. (2011) The lessons of civil defense federalism for the homeland security era, Journal of Policy History, 26, 3, 354-383.

Rudolph,J. (2002) Scientists in the classroom: the cold war reconstruction of science education (Palgrave: New York).

Scott,J. (1990) A Matter of Record (Cambridge, Polity Press)

Seabourne, M. (2006) A 'golden age' of school building? Oxford Review of Education, 11, 1, 97-103.

Statement by Bradshaw Mintener, Assistant Secretary of Health, Education and Welfare before a Committee on appropriations, 1956 estimates - civil defence activities, DHEW, Book R: Records Of Dean Snyder, FCDA Delegations To DHEW - Goals, Reports And Miscellaneous - Office Of Defence Coordinator, 1954 - 55, files of Dean Atlee Snyder, 1940 - 1958, General records of the DHEW,19351981, RG 235, NACP.

Steedman,C. (1992) Past Tenses: Essays on writing, autobiography and history (London, Rivers Orman Press)

The Civil Defense (Adult) Education Program, Administered by the U.S. Office of Education Civil Defense Education Branch, December 1958 - June 1971. Container 2: Conferences, 1966 - 1970 (8 folders) THRU Correspondence with states - letters of protest 1968 - 71, DHEW, OE CD records, RG 12 , NACP. 
Thelen, K. (2004), How Institutions Evolve: The Political Economy of Skills in Germany, Britain, the United States and Japan (New York, Cambridge University Press)

Tight,M. (2010) The Golden Age of Academia: Myth or Memory, British Journal of Educational Studies, 58,1, 105-116.

TV Projects for Civil Defense Adult Education, undated memo, Container 17 Snyder, Dean (DHEW, Defense Coordinator), Correspondence, 1959 - 1962 THRU Educational Television, 1966, files of Dean Atlee Snyder, 1940 - 1958, General records of the DHEW,1935-1981, RG 235, NACP. US Department of Health, Education and Welfare (1962) Statistical summary of Education 1957-1958 (Wahington: United States Government Printing Office). 